\title{
ETHNICITY AND POLITICAL PLURALISM IN KENYA*
}

\author{
Shilaho Westen Kwatemba
}

\author{
Shilaho Kwatemba is a PhD Candidate in the Political Studies Department, \\ University of the Witwatersrand, Johannesburg \\ e-mail:wshilaho@yahoo.com
}

\begin{abstract}
This paper focuses on the salience of ethnicity in Kenya since the return to political pluralism in 1991. It argues that ethnicity as a variable in Kenya's political processes dates back to the colonial period. Successive governments in that country, beginning with the Jomo Kenyatta state in 1963, perfected the aspect of ethnicity that dovetailed with patronage, rent-seeking and prebendalism to the detriment of the nation state. The paper engages with the theoretical underpinnings of ethnicity in an attempt to understand its overwhelming influence on Kenya's politics, especially in the multiparty era. The thrust of the argument is that unless there is the political will to re-engineer Kenya's polity both politically and constitutionally the nationbuilding project will remain convoluted, frustrating and stillborn.
\end{abstract}

\section{INTRODUCTION}

Kenya is among the few African countries that, for a considerable period after independence, maintained a reputation for uninterrupted peace. This was a remarkable achievement given that the country has had its fair share of turbulent times. The Kenyatta state (1963-78) muzzled nascent plural democracy a few years into independence. Subsequently intermittent political assassinations characterised the single-party era. A system of violence as an alternative to the free trade in ideas eventually mutated into a phase of ethnic clashes following Kenya's return to multiparty democracy in the early 1990s.

* This paper was presented during a workshop on Kenya with the theme Conflict Resolution in Kenya: Taking Stock of a Political Crisis at the University of the Witwatersrand, Johannesburg, on 18 July 2008. 
All these events served to put the country on a perilous political trajectory. With the banning of multypartyism robust debate was muzzled, political intolerance set in and opposition became subterranean. Rather than address the canker gnawing away at the country's body politic successive political leaders indulged in a dance of self-deception which exacerbated challenges such as the endemic but mundane corruption that faced the country and, alarmingly, bought into the self-constructed myth of a peaceful country.

The violence that erupted in the wake of the controversial 2007 presidential election tested Kenya's political stability more than ever before, almost plunging the country into full-blown civil strife. Like a festering wound it exposed the structural rot embedded in the country's system.

A confluence of irregularities pertaining to land allocation, an overbearing presidency, a pervasive culture of impunity, and ethnicisation of power, malfeasance and sheer mendacity among both the political elite and the rabble almost pushed Kenya over the precipice (GoK 2008, pp 22-36).

The crisis, however, also presented Kenyans with an invaluable opportunity to renew the country through institutional and constitutional reforms and it would be regrettable if the political elite squandered that opportunity and once more began playing politics with the grave issues facing the country. This paper, therefore, attempts to situate the interface between ethnicity and pluralism within the ambit of Kenya's historiography. The question is: why was ethnicity so overtly politicised in a politically pluralist Kenya?

The paper traverses Kenya's political landscape from the colonial period to the present, indicating that ethnic politics in the country has evolved over the years with the aid of politicians. The first section attempts to locate the origins of ethnicity in colonialism. The second and third sections form the theoretical framework within which ethnic politics in Kenya is analysed and interpreted. The third section specifically shows that corruption in Kenya's polity is inextricably intertwined with complex and complicated political relationships that provide the scaffolding for the maintenance of power.

In the fourth and fifth sections the paper attempts to analyse the salience of ethnicity in Kenya under both one-party rule and political pluralism. It concludes that whereas ethnicity manifested itself in both phases, in the one-party system the contest was often confined to intra-ethnic friction and rivalries among clans, sub-tribes and regionalism. In the multiparty system ethnic communities tended to collapse their internal differences into political contestations over state control. The paper, however, recognises that ethnicity did not neatly project itself in clearly defined colours in the two phases. There were nuances in the sense that ethnic solidarity perennially proved elusive in certain ethnic communities, such as the Luhya. 
The sixth section dwells on political alliances in the run-up to the 2002 general elections and their aftermath and tries to argue that whereas the Kenya African National Union (Kanu) lost the power it had maintained since independence in 1963, structural and institutional challenges inherent in Kenya's politics made it difficult for the country to institute the political, institutional, and constitutional reforms for which Kenyans yearn.

The seventh section grapples with the hotly contested and disputed 2007 presidential election, which nearly plunged the country into civil war. The most important lesson from the 2007 election is that though it is more than four decades since Kenya achieved independence separatist and sectarian inclinations among both politicians and their followers threaten the national civic ethos.

In conclusion the paper recaps some of the salient issues at the core of Kenya's postcolonial crisis and suggests ways in which the country might break out of the apparently immovable political gridlock that faces it.

\section{HISTORICAL BACKGROUND}

One of the most enduring attributes of the legacy of colonialism in post-colonial Kenya was a sense of ethnic division that found expression not only in terms of group identity, but also became a mobilising agent in pursuit of economic interests. This complex process of class formation intersected with attempts by the colonial regime to manage the attributes of a traditional society and its mobilisation to develop a colonial capitalist market. Therefore it is not easy to understand the ethnic incubus in Kenya's politics unless one goes back to colonial capitalism and its uneven impact on various ethnic groups (Kitching 1980, Leys 1975, Swainson 1977).

The origins of ethnic consciousness as manifested in Kenya's political processes lay partially in the arbitrary way in which the British colonialists based administrative boundaries and local government on cultural and linguistic lines, a decision informed by an assumption that Africans lived in tribes, so tribes must constitute the basis of colonial administration (Sandbrook 1985, pp 49-50).

Kenya, like most colonies in Africa, was the invention of colonialists, an invention which seemed to have been flawed from the start and hence was a crisis in the making because the invented territory brought together different ethnic communities, some of which had little or nothing in common culturally. Other communities were mutually hostile. This does not mean that cultural homogeneity is a sine quo non for political stability. What can be said is that culturally diverse ethnic communities will clash unless those in authority make a deliberate effort to engender coexistence among them.

Kenya has more than 42 disparate ethnic groups. These groups per se do 
not pose a threat either to the stability of the nation state or to themselves, since people do not fight one another simply because they have different cultural and linguistic attributes. Recurrent animosity among ethnic communities in Kenya was the result of the politicisation of ethnicity. Postcolonial leaders seem to have approached ethnicity with the same intent as the colonialists, failing to infuse a national civic culture within the country's body politic because those at the centre of power pursued insular, sectarian and self-serving interests.

On the threshold of independence it was a sense of nationalism, not ethnic considerations, that guided some of the decisions made by nationalist politicians. In 1961, for instance, Oginga Odinga and his fellow nationalists refused to enter independence negotiations with the British colonialists until Jomo Kenyatta was released from detention (Sunday Standard 4 2007). The reasoning was that to enter negotiations while Kenyatta and others were still in detention would be tantamount to betraying the collective cause that was supposed to bind all freedom fighters irrespective of their ethnic origin.

However, after independence in 1963 the leading political parties, the Kenya African National Union (Kanu) and the Kenya African Democratic Union (Kadu), became amalgams of ethnic groups. Kenyatta used an ethnic cabal to consolidate power in the office of the president and marginalised his erstwhile liberation colleagues such as Odinga (Throup \& Hornsby 1998, pp 12-20). To stave off opposition both the Kenyatta and Moi states conveniently imposed a one-party government on the pretext that it was necessary for the promotion of national unity and nation-building (Mutua 2008, p 40).

Kenyatta, in cahoots with a clique of politicians with ethnic inclinations, interfered with the doctrine of separation of powers by emasculating the judiciary and legislature and creating an imperial presidency soon after Kenya's independence. Most of the politicians who wielded political and economic power during Kenyatta's regime hailed from the Kikuyu community to which he belonged. This coterie regularly changed the Constitution in pursuit of unbridled power. The net effect was the creation of a presidential behemoth that resulted in a one-party dictatorship. Between 1963 and 1978 the Constitution was amended numerous times with the express object of consolidating power in the presidency (Ogot \& Ochieng' 1995, p 106). The amendments made nonsense of the whole idea of independence since they were a throwback to the authoritarian patterns of colonial rule (Haugerud 1995, p 51).

In addition to showing a lack of regard for the Constitution Kenyatta smothered a nascent multiparty democracy and established one-party rule, which created a veneer of well-managed ethnic relations beneath which lay repressive strategies such as detention without trial for dissenters (Osaghae 1994, p 6). This potentially cataclysmic approach to ethnic differences serves to mask ethnicity 
but it can neither lead to the elimination of ethnic cleavages nor can it extinguish them through repression or assimilation. To ensure peaceful coexistence among different ethnic groups ethnic cleavages must be managed (Osaghae 1994, p 6).

At the height of the post-election violence in January 2008 the post of prime minister was reinstated through a power-sharing agreement between the protagonists. The intensity of the violence-hitherto unknown in Kenya-showed how horribly bad Kenya's power contestations can go. If the post had not been cavalierly eliminated from the independence Constitution the violence might never have broken out.

Under Kenyatta the exercise of political power was so informal that the line dividing the then ruling party, Kanu, and an ethnic grouping called the Gikuyu, Embu, Meru Association (Gema) was invisible and Gema and Kanu office bearers were one and the same (Himbara 1994, pp 27, 94-95). In fact, under Kenyatta, Kanu was almost moribund as a functioning political party, making it easy for the Gema association to supplant it as the de facto ruling party (Throup \& Hornsby 1998, p 37) and to dominate Kenya's business and political landscape with abandon.

The shift from Kenyatta to Daniel arap Moi in 1978 saw Kanu assume a prominent place in Kenya's politics. Political careers began and ended with Kanu. Moi centralised power in his person and the party became the centre of political conflict. Even ordinary Kenyans could only ignore Kanu at the pain of personal grief. A Kanu membership card became almost essential for advancement in the civil service or access to loans and other state services (Throup \& Hornsby 1998, p 37).

In the course of my research I talked to a Kenyan who remembered having been asked to produce his Kanu identity card in 1985 by the notorious Kanu youth wingers before being allowed into a market in a rural market centre. ${ }^{1}$ Another Kenyan I spoke to remembered that in the 1980s it was mandatory for adults in Kenya to carry their Kanu identity cards most of the time. ${ }^{2}$ The Kanu youth wing was composed of both young and not-so-young people, particularly males, with the task of implementing party resolutions at grass-roots level. Single-party rule was at its zenith in the 1980s and any adult who failed to prove his or her Kanu membership might be accused of being a dissident.

Moi, who had served as vice-president for 11 years, ascended to the presidency after Kenyatta's death. He made no pretence of bringing in the sociopolitical and economic reforms for which Kenya was crying out after the bruises inflicted by his predecessor in the form of state repression, political assassination and the marginalisation of certain communities, particularly the Luo (Mutua 2008).

1 Interview with Professor C J Odhiambo, Johannesburg, 18 October 2008.

2 Interview with Dulo Nyaoro, Johannesburg, 30 October 2008. 
Moi stated from the outset that he would follow Kenyatta's style - his slogan was 'footsteps'. However, with time, the 'footsteps' ideology changed from Moi following in the footsteps of Kenyatta to that of everyone else following in those of Moi (Throup \& Hornsby 1998, p 38).

Moi's ideology, called 'nyayoism', comprised a plethora of elements such as Christian morality, developmentalism, nationalism, anti-tribalism, and even African socialism. It was more of a concoction of the triple elements of 'peace, love and unity', through which Moi attempted to stamp his political idiosyncrasies on Kenya's political arena, than a well thought out and enunciated political philosophy. Contrary to its portrayal as an avenue for galvanising people for development projects, 'nyayo' or 'nyayoism' was a nebulous ideology, which, reduced to its lowest common denominator, equated opposition against Moi's rule with 'anti-nyayoism'.

Failure to subscribe to it was construed as dissent against the Moi government (Katz 1985, p 158). Moi did not spell out clearly the relationship between his 'ideology' and the ideals and ethos he wished to impose upon Kenyans as firstgeneration African leaders such as Julius Nyerere did with Ujamaa (African socialism) or Kenneth Kaunda with humanism. While scholars grappled with the essence of 'nyayoism' Moi used it to forge for himself the image of a forgiving patriarch and statesman by pardoning political detainees and ordering them released from detention (Khapoya 1988).

Perhaps because he had worked under Kenyatta for so long Moi was not capable of leading the reform of the many socio-economic and political challenges that weighed down the country. During his time as Kenyatta's vice-president he had given total loyalty, so, once in office, he expected members of his government to mimic his sycophancy (Friedman-Sabar 1997, p 27). Most of his contemporaries perceived him as a political lightweight (Morton 1998, pp 128-30; Russell 1999, pp $69,71)$. Compared to the power brokers in Kenyatta's inner circle such as Charles Njonjo (Attorney General), Njoroge Mungai (Minister of Foreign Affairs) and Mbiyu Koinange (Minister of State), who were better educated and had the Kikuyu 'pedigree', Moi was seen as an intellectual Lilliputian and a political neophyte. As such the Kenyatta coterie concluded that it had no reason to fear his political game plan. Its members could not have conceived that Moi had a realistic chance of succeeding the geriatric Kenyatta (Morton 1995, pp 128-30; Russell 1999, pp 69, 71). However, once in office he decided to make up for his lack of charisma by resorting to direct populist appeals in a bid to create a power base distinct from that of Kenyatta (Throup \& Hornsby 1998, p 27).

It was the lingering knowledge that most of his contemporaries in the Kikuyu community had a dim view of him that partly accounted for Moi's paranoid rule from 1978 to 2002. His mien as a master of political poker began in 1982 as a result 
of an abortive coup staged by junior Air Force officers. However, his clampdown on dissidents preceded the attempted coup (Atieno Odhiambo 2002, p 227; Badejo 2006, pp 102-106). His rule was informed by a sense of political insecurity almost bordering on paranoia. This was manifested in the number of times he reshuffled his Cabinet, not as much because Cabinet members were inefficient but as a way of scuppering the development of alternative centres of influence (Kanyinga 1998). He came across as a mistrustful, calculating, scheming, sly politician who had no qualms about reneging on his promises (Daily Nation 24 December 2002). The corollary was that the politics of musical chairs became Kenya's characteristic, at the expense of economic and political stability. Moi's raison d'être seemed to be to keep his political feelers in the air for any whiff of dissent or disloyalty.

\section{THEORIES OF ETHNICITY}

The link between ethnicity and African politics was the subject of academic discourse long before many African countries embraced multiparty politics. In this section we will engage with some of the theories in the field of ethnicity as a theoretical backdrop against which to interpret Kenya's transition from singleparty rule to political pluralism; insights which may enhance understanding of why Kenya was prone to political instability after multiparty elections.

Brown (2000, p 6) defines an ethnic group as that community which claims common ancestry and sees the proof of this in the fact that its members display distinctive attributes relating to language, religion, physiognomy or homeland origin. Young argued that ethnicity is a concept that has no significance in isolation. His thesis is that any analytical attempt should begin from the premise that ethnicity is a relational concept. According to Young \& Turner (1985, p 139) 'we' can only find relevance in 'they'. In most cases those who define themselves as 'we' ascribe to themselves positive attributes and give negative and disparaging ones to the 'they' group. Lonsdale (2004, p 76) referred to this process as 'ourselves-ing' and 'othering' contained in moral ethnicity and political tribalism respectively. Brown (2000, p 6) states that members of an ethnic group believe there is a natural and emotional link between an individual and a community which makes ethnic consciousness the central component of individual identity.

Kasfir (1976, p 77) argues that some of the attributes of ethnicity, such as language, territory, and cultural practices, are objective and their objectivity is partially underscored by the fact that they are seen by both insiders and outsiders of a given ethnic community as significant indicators of identity to such an extent that they may be used as bases for political mobilisation.

However, according to Young (1976, p 48), ethnic communities change constantly and the defining attributes of ethnicity are not fixed. In one political 
situation these attributes may include language, territory, political unit, cultural values or symbols, in another some of them may be absent, so the extent to which they are defining characteristics varies according to circumstances. In consonance with Young's argument Bates (1983, p 165) holds that ethnic groups lack an 'objective basis' and are dynamic and sometimes 'invented'. Correspondingly, Chazan, Leiw, Mortimer, Rothchild \& Stedman (1999, p 108) argue that ethnicity is an issue of subjective perception with regard to common origins, historical memories, ties and aspirations.

In the 1950s and 1960s ethnicity in Africa and other countries defined as less developed was analysed through the primordial ${ }^{3}$ approach. It was believed at the time that ethnic conflict could only be understood through this approach (Brown 2000, p 9; Stone 1983, p 85). The reasoning was that political behaviour in such 'backward' societies was likely to be driven by emotion and instinct and based on ancestrally based 'tribal' affiliations. There was a misconception that the processes of modernisation would lead to more rational forms of political behaviour as development occurred, promoting either a universalistic rationality or an intrinsically democratic form of civic nationalism focused upon identification with the modern state rather than on the community of common ancestry (Brown 2000, p 9).

These approaches connoted atavism, so ethnicity was seen as a problem facing societies that were yet to fit into modernity. The existence of ethnic tensions in those societies was interpreted as a sign of backwardness and lack of 'civilised' ways of behaving. Thus ethnic tendencies were described as 'outbursts of inward and backward looking irrational intolerance' (Brown 2000, p 9). However, an attempt to portray ethnicity as being peculiarly an African and, by extension, Third World problem was contested. Stone $(1983, \mathrm{p}$ 85) cites a number of countries that emerged in the 20th century in Europe - Bulgaria and Yugoslavia to name but two - to dismantle the notion that ethnic nationalism was a primordial vestige of an era gone by and was confined to Africa.

At the threshold of independence some analysts imagined that primordial tendencies were the preserve of the masses in the rural areas and that the elite were immune to ethnic stereotypes because of their formal education (Hyden 1983, p 72). Beneficiaries of Western education were considered detribalised and disabused of the primordial thinking from which the rural masses needed to be weaned (Stone 1983, p 85). Political ethnicity is an enmeshing phenomenon and this negates the claim that the ethnic sensibilities of the elite differ substantially from those of the masses.

3 The primordial bond is the belief that one is born into a particular linguistic, racial or homeland community and therefore inevitably feels an overwhelming emotional bond with that community (Brown 2000 p 6). 
In Mamdani's reading it is the manner in which colonialists incorporated Africans into the modern state that set in motion the deft manipulation of ethnicity by the elite in postcolonial Africa. The elite ascribed to themselves the rights of citizenship while the masses remained 'tribal' beings (1996). Ironically, political mobilisation and modernisation, which Hyden mentions as issues that attenuate ethnic consciousness in Africa, are the very ones that enhance a sense of ethnic tension among communities on the continent. In consonance with Hyden's thesis Horowitz further argues that, contrary to the views of earlier analysts, ethnicity in Africa is not disappearing in proportion to advancement in modernisation. In his words: 'it has proven not to be an anachronism and the elites earlier considered to be leading people away from ethnic affiliations were the ones found to be in the forefront of ethnic conflict' (Horowitz 1985, p 97; Bates 1983, p 165).

Horowitz argues that social mobilisation enhances ethnic competition, particularly in a competitive modern sphere. Horowitz's thesis is that it is the competitor in the modern sector rather than the resident in rural Africa who feels the anxieties and insecurities of change and it is therefore this individual who is most likely to exploit tribalism for self-serving ends (Horowitz 1985, p 100; Bienen 1983, p 103). The question of whether ethnicity masks class interests is subject to debate. However, what cannot easily be disputed is that elites interpret integration and communal difference with other members of their communities and, in doing so, attempt to bridge the gap between themselves and the non-elites (Bienen 1983, p 103).

Brown (2000, pp 6-7), who analyses ethnicity and nationalism along the same lines, is of the view that the two concepts are intertwined. Ethnicity mutates into nationalism once it is actively and self-consciously mobilised in order to legitimate claims that an ethnic community has some rights of self-determination. To Brown a primordial approach depicts the nation as based upon a natural, organic community, which defines the identity of its members, who feel an innate and emotionally powerful attachment to it. Primordialism held that humanity has evolved into distinct, organic communities, each with its own language and culture, with each individual's identity derived from his or her location within one such community (Brown 2000).

Primordialism thus explains the occurrence of conflict and violence in modern nationalist politics as being caused by a disconnect between modern states and the boundaries of natural national communities which deserve and seek political autonomy (Brown 2000, p 6).

Instrumentalism is another theory used to interpret challenges stemming from ethnicity in Africa. While primordialism foregrounded culture as the basis of ethnic identities in Africa, according to the instrumental framework African politics is best analysed through the traditional-versus-modernity dichotomy. 
This theory holds that ethnicity becomes a defining criterion when groups are competing for scarce resources and values (Young \& Turner, 1985, pp 139-40).

In Africa access to power is important to various ethnic groups within a nation state because of the extensive intervention of the African state in many spheres of people's lives (Kanyinga 2001, p 354-5). Therefore the awesome power of the African 'leviathan' (Mutua 2008, p 40; Lonsdale 2008) forces individuals and ethnic groups to seek control of the state, or at least have some access to it as matter of security (Nnoli 1995, p 6).

Instrumentalism does not conceptualise ethnicity as an entirely bad thing. Thus ethnicity can take the instrumentalist angle either when members of a community want to extract advantages from the nation state or in an attempt to wriggle out of deprivation which they believe is politically induced (Young 1985, pp 139-40). Ethnic nationalism is analogous to a Janus face in the sense that despite its disruptive side ethnic-based movements have served as counter forces to the centralising and hegemonic ambitions of the modern territorial secular nationstate (Kagwanja 2003). Furthermore, ethnicity accords an individual a sense of belonging, especially in an impersonal, solitary and alienating urban setting prone to insecurity and destructive competition as a result of commodity markets (Nnoli 1995, p 4). In other words, ethnic identities have provided social safety nets which have cushioned many Africans from poverty, disease and illiteracy in the face of the debilitating effects of structural adjustment programmes (SAPs) and other policy excesses of globalisation (Kagwanja 2003).

Nnoli (1995, pp 4-5) argues that ethnicity is pivotal to the democratisation of a given nation state since it acts as a mobilising agent against issues of domination, oppression and exploitation by an unresponsive government. In this regard ethnicity is consistent with democratic ideals in which there is a quest for social justice, equity in distribution of resources, and accountability. The positive attributes of ethnicity are often subsumed by its negatives ones, since the latter are more dramatic, even catastrophic (Nnoli 1995, p 8). The major inadequacy of the instrumentalist approach is that it panders to colonial and anthropological stereotypes of Africa as a continent comprising stagnant and unchanging tribal societies (Berman 1998).

Instrumentalism conceptualises African politics as characterised by the manipulation of ethnic identities and loyalties for political and economic ends. Cynics disillusioned by the prevalence of the mercenary character and graft in post-independence African politics are among those who subscribe to this theory (Berman 1998).

The primordial and instrumentalist approaches appear to view the issue of ethnicity from two diametrically opposed standpoints. Whereas the latter factors into its interpretation terms such as 'contingent', 'situational', and 'circumstantial', 
as used in ethnic-based politics in pursuit of material advantage, the primordial model insists on the non-instrumental, deeply affective and emotional character of ethnicity. These attributes set instrumentalism apart from other bases of political identity and mobilisation (Berman 1998; Young 1985, pp 139-40).

Both primordial and instrumental theories are faulted for their inability to ground the understanding of ethnicity in contemporary African circumstances. Primordialists seem to gloss over the question of ethnicity and do not regard ethnic groups in Africa as being real (Ake 2000, p 94). Olorunsola (1972, p 4) cautions that the politics of ethnicity in Africa will not vanish on their own. If ethnic politics are ignored in the misguided hope that they will iron themselves out they will lead to disastrous outcomes, and if we merely paper them over they will prove fatal. Since this warning was issued Africa has seen some of the most horrendous acts of ethnic violence. The 1994 Rwanda genocide was probably the lowest point, proving that once ethnicity is mobilised it can easily lead to cataclysmic consequences. Instrumentalists argued that ethnic politics is made possible because of the twin attributes of manipulability and exploitability of ethnicity (Ake 2000, p 94).

One gap in the instrumentalists' theory is that it does not take account of the role played by the populace in ethnic politics in Africa. The rationale behind mass participation in ethnic politics is not easy to figure out. The thinking prevalent in modernisation theories that the masses exhibit a herd instinct so the political elite find them malleable does not stand up to scrutiny (Horowitz 1995, p104). Implicit in this thinking is that non-elites are victims of 'false consciousness' because they serve the interests of the political elite under the impression that those interests are theirs.

In Kenya the masses, through what Kanyinga (2001, pp 354-5) calls 'ethnicity from below', subject the political elite to pressure to locate itself strategically within the state so as to appropriate development and resources. This mode of ethnicity thrives on the logic of 'eating through one of our own'. Thus 'it is our turn to eat because another group has eaten becomes the organising slogan around which other considerations revolve'. As such, the politicisation of ethnicity is an enterprise that involves both the political elite and the masses.

Though it is tempting to read Kenya's politics through the instrumentalist prism, it is controversial to state that the masses in Africa are misled by politicians in pursuit of the pay-offs of the politics of extraction (Horowitz 1985, p 104). Horowitz (1985, p 105) asserts that it is difficult to reconcile this assumption that the masses follow the thinking of politicians uncritically, with compelling evidence from Africa and Asia indicating that non-elites are not ignorant about politics. Moreover, the masses in Kenya and elsewhere are not a homogenous entity and thus do not participate in politics in pursuit of identical interests. 
A constructivist approach to ethnicity debunks the existence of ethnic groups. Constructivists characterise those who insist on the reality of ethnic groups as people involved in ideological consciousness, which means the portrayal of ethnicity as a phenomenon which renders it susceptible to manipulation and mobilisation for the achievement of certain political and economic ends (Brown 2000, p 20; Ajulu 2002, p 252). The constructivist model understands ethnicity as socially constructed but not a fixed primordial identity. However, the primordial aspect cannot be entirely dismissed or it would not be possible for us to understand ethnic mobilisation (Young \& Turner 1985, p 140). As Horowitz (1985, p 105) argues, in order for the elites to deflect mass antagonisms on to other ethnic groups such a deflection must first resonate with mass sentiments, apprehensions, and aspirations.

According to the constructivist theory ethnicity is the result of a combination of dynamic and conflictual political, economic and cultural forces which are both external and internal to developing ethnic communities (Berman 1998). The constructivist understanding of ethnicity is premised on the view that ethnicity is an outcome of deliberate and conscious effort by both members of a given community and those from outside to define that community (Le Vine 1997, p 50).

Le Vine observes that the cognitive dimensions of ethnicity include not only ideas, perceptions, and attitudes about the self, the group, and others, but also the ascriptive boundaries that serve to distinguish one group from another. In Brown's analysis constructivist approaches suggest that national identity is constructed on the basis of an institutional or ideological framework which offers simple, and indeed simplistic, formulas of identity, and diagnoses of contemporary problems to otherwise confused or insecure individuals (Brown 2000, p 20).

Closely related to the instrumental approach is the situational one, according to which ethnic identities are not natural and instinctual to any given community but should instead be seen as resources deployed by politicians in pursuit of their common interests, which, in most cases, are political and economic (Brown 2000, p 13). Young (1985, p 139-40) argues that the effect of ethnicity on politics is contingent upon its instrumental dimension. Situationalism avers that people's responses change depending on the threats and options they face (Brown 2000, p 13).

The main thrust of a situational approach to ethnicity is that the boundaries of an ethnic group contract and expand in different situations. For instance, when opposed to another major group, an ethnic group's membership is defined inclusively, but when a situation arises in which the group projects internal divisions its membership tends to be restrictively defined (Bates 1983, p 165). As such, ethnicity is a fluid phenomenon, even though it may appear immutable in conflictual situations. Le Vine (1997, p 47) argues that group boundaries may shift as groups divide, merge, erode, aggregate, or redefine themselves over time. 
Young (1993, pp 21-25) believes the various approaches to ethnicity are enmeshed. Hence he argues that ethnicity involves three interactive dimensions: primordial, instrumental, and socially constructed. The elaborate quote below is apposite in capturing, although in a summation, his understanding of the concept of ethnicity:

Recent debate about ethnicity suggests that it involves three interactive dimensions: primordial, instrumental and socially constructed. Ethnic identity often involves deep emotional attachments to the group, supplies an internal gyroscope and cognitive map through which the social world is perceived, and histories of selfhood in a web of primordial cultural meanings. In everyday political and social interaction, ethnicity often appears in an instrumental guise, as a group weapon in the pursuit of material advantage; thus its activation is contingent, situational and circumstantial. Ultimately, all identities are socially constructed, a collective product of the human imagination ... Social identities are invoked, used, and rewoven in the myriad encounters of everyday life at both the individual and group level. Combining these three perspectives, we may conclude that ethnicity rests upon a singularly potent set of symbolic resources and affective ties, but operates in a fluid and changing way in the political arena. The units of identity are not themselves timeless, but evolve in social praxis.

Young 1994 in Le Vine 1997

The fluidity of ethnicity features prominently in literature in Africa. Thus Young (1976, p 5) argues that because the definition of groups is perpetually changing any theory of ethnic conflict must include change as a central issue.

\section{THEORY OF POLITICAL RELATIONSHIPS}

African politics largely thrives under a system of neopatrimonialism, although to varying degrees (Bratton \& Van de Walle 1997, p 61). Patrimonialism is defined as a type of government organised as an extension of the ruler's own household. The ruler makes no distinction between his own private property and that of the state. His rule over the territory is personal and arbitrary, without recourse to law or administrative predictability, as political authority is based on clientelism (Van de Walle 1994, p 131).

Analysts of African politics realise that attributes characteristic of patrimonial systems of rule have survived among the leaders of the new nation states, though 
patrimonial systems were thought to have disappeared from the African political scene. These leaders exhibit all the traits of medieval kings and sultans save for the titles. The concept of neopatrimonialism was born out of this striking similarity (Cooper 2002, p 96).

Patrimonialism is contrasted with rational-legal authority in which power is exercised in accordance with explicit legal structures specifying procedural rules and norms and serving to promote well defined public goals. In a rationallegal authority, there is a distinction between the public and private spheres and written laws and the bureaucratic institutions characterise the exercise of authority. Leaders are prevented from bringing their caprices and whims to bear on individuals' liberties and their property (Bratton \& Van de Walle 1997, p 62). It is through these lenses that the inclination towards arbitrariness without due regard for the rule of law which defined both the Kenyatta and Moi regimes could be interpreted. Under these leaders Kenya's Constitution was casually amended several times to entrench repression through the centralisation of power in the presidency (Mutua 2008; Ogot \& Ochieng' 1995). When Moi ascended to power his government hurriedly passed a motion in the National Assembly making Kenya a de jure single-party state (Widner 1994, p 58). Kenyatta ordered the arrest of dissenters who criticised his government on the floor of the National Assembly, which was a grave subversion of the rule of law, which accords members of the National Assembly immunity against remarks they make during parliamentary sessions.

Neopatrimonialism under Moi was exercised through a political elite drawn from his Kalenjin community. After a 1982 coup attempt Moi started building his own 'kitchen Cabinet', drawn largely from his community. It should be noted that the Kalenjin community comprises a mosaic of various sub-tribes and Moi's inner circle comprised power brokers from his Tugen and the neighbouring Keiyo communities of the larger Kalenjin ethnic group in the Rift Valley province (Ajulu 1993, p 4).

It is instructive to note, too, that Moi's Kalenjin power base was not cohesive either in a one-party state or in a multiparty democracy. He was invariably suspicious of the two most populous, most politically mobilised, and most economically developed Kalenjin subgroups, the Nandi and Kipsigis. Ironically, the Marakwet, hitherto considered part of the ruling troika together with the Keiyo and Tugen, posed a challenge to Moi's government in 1997 over perceived government bias towards the Pokot, another Kalenjin sub tribe, with which they were locked in a cattle-rustling dispute (Kagwanja 2001, pp 81-2).

As the principal patron Moi could not afford to build his own version of the one-party monolith on political carryovers from Kenyatta's era. He needed a retinue of new clients whom he could trust as he sought to consolidate his hold 
on power and check potential opposition. However, the widespread perception that the Kikuyu elite lost out during Moi's rule does not stand up to scrutiny in as much as it seems to have informed the community's opposition to Moi. In 1996, 18 years into Moi's rule, a highly confidential study of the makeup of the executive offices of the civil service showed that the Kikuyu, who comprise a fifth of the country's population, dominated the civil service (Morton 1998, p 212).

However, Moi, a consummate politician, was able to hide his intentions through a series of populist gestures aimed at endearing him to the masses (Ogot \& Ochieng' 1995). If there was any difference between Moi's and Kenyatta's presidencies it was that the former came across as an indefatigable leader, crisscrossing every nook and cranny of the country, ostensibly on inspections of and to launch development projects.

Moi invariably turned these tours into public rallies at which he made hortatory speeches (Morton 1995, p 170). This was a far cry from the almost reclusive and inaccessible Kenyatta, who hardly ventured into the rural areas, partly because of his age and partly because of hostility from communities such as the Luo (Khapoya 1980). During these forays Moi took the trappings of power into far-flung areas which had never seen the country's leaders at close quarters. Therefore, in a way, he succeeded in demystifying the institution of the presidency in Kenya but did not change its image as a predator and an ogre (Mutua 2008, p 40).

In as much as Moi banned ethnic welfare societies, which were springboards to political careers and vehicles for constituency building, because he viewed them as fostering ethnicity (Widner 1994, p 58), his entire presidency was characterised by the deft manipulation of ethnicity for political point scoring. He built his regime on a coalition of smaller ethnic communities and infused in them the fear of their numerically superior counterparts, encouraging them to cling together lest they be subdued. Moi, like Aguiyi Ironsi, one-time military strongman in Nigeria, ambitiously tried to ban or eradicate ethnicity while, ironically, adeptly exploiting it for political gain. Moi's contradictory approach to ethnic politics bears testimony to the resilience of the phenomenon in Kenya's polity (Osaghae 1994, p 6).

\section{ETHNIC POLITICS IN THE ONE-PARTY STATE}

In this section an attempt will be made to understand how ethnicity manifested itself under single-party rule in Kenya. Posner (2007) asserts that ethnicity is a strong criterion for the choice of candidates in both single-party and political pluralism. A distinction in the way in which ethnicity manifests itself in the two political systems lies in the dimension of cleavage politicians exploited.

Under the one-party system individuals tend to identify themselves in terms of ethnic identities which define them as members of small localised groups 
based on tribe, sub-tribe or clan. By contrast, in a multiparty setting political competition creates incentives for individuals to see themselves in terms of ethnic identities that define them as members of large blocks, usually based on religious, linguistic, or regional distinctions (Posner 2007).

Perhaps the greatest irony of Kenya's shift from single-party rule to political pluralism was that the then ruling party, Kanu, decided to capitalise on ethnicity in its bid to extract political mileage from competitive politics. This development must have rudely awakened most Kenyans to the recrudescence of ethnicity in the country's politics. Instead of the political landscape changing in consonance with the change in terms of freedom of the press, association, and free trade of ideas among competing political parties the parties that emerged camouflaged raw ethnicity (Apollos 2001). For instance, Kanu, led by Moi, became a party of Kalenjins and the minority tribes. Odinga dominated the FORD-Kenya party, which was mainly associated with the Luo and the Bukusu sub-tribe of the Luhya. The Kikuyu dominated two political parties - the Democratic Party (DP), led by Mwai Kibaki and the FORD-Asili Party, led by Kenneth Matiba (Apollos 2001).

Ethnicity found expression in Kenya's politics because most Kenyans felt alienated from the state, a lacuna whose provenance lay in the colonial period. The country came into being by means of an arbitrary process that paid no regard to the linguistic, cultural, or even religious identities of peoples who were lumped together in the political space designated as Kenya. Since the intention behind the formation of the state was administrative control and economic exploitation despotism was the hallmark of both the colonial governors and the political elite that succeeded them (Apollos 2001).

In the light of the above the nation-state project, not only in Kenya but also in many other African countries, was doomed from the start, since it was haunted by the fear of instability, disintegration and anarchy (Kagwanja 2003). Consequently, to most Kenyans the state was illegitimate and intruded on the lives of citizens without delivering the most basic of functions. The state also had a propensity for arbitrariness and selective application of the rule of law, often biased against people without means as well as against those who fell foul of the government of the day.

This lopsided legal framework resulted in discontent and disillusionment, if not outright revulsion, making it difficult to build a national democratic culture (Mutua 2008, pp 21-2). This created a disjuncture between the state and the members of ethnic groups who felt excluded from the benefits derived from control of the state. Consequently, there was an inclination towards an affective politics of ethnicity among Kenyans who were excluded either directly or indirectly from state largesse. 
Clampdowns on dissidents, a hallmark of single-party rule in Kenya, stymied the overt mobilisation of ethnicity, with the presidential behemoth providing a bulwark against opposition during Moi's rule. Moi promoted a political practice whereby ethno-regional delegations paid him what were euphemistically called courtesy visits at various state houses as well as at his home in Nakuru district (Mutua 2008, p 23).

Ethnic kingpins within his government invariably mobilised and corralled a mélange of grassroots leaders into sycophantically affirming their unstinting loyalty to him and to Kanu. These rituals bordered on personality cults in the sense that Moi was portrayed as the only Kenyan capable of ruling and as ordained to rule (Haugerud 1995). A politician within the ruling party deemed to be less enthusiastic about these exhibitions of showmanship and sycophancy risked placing his or her political career in jeopardy and being accused of insubordination.

Given the restrictive political space politicians found it difficult to whip up ethnic sentiment as a launch pad for their onslaught against the one-party citadel. Firstly, political rallies by opposition leaders were technically proscribed, since the process of acquiring a licence from the provincial administration was extremely laborious. The provincial administration was so beholden to the executive that it was impossible for the bureaucrats to grant permits for political rallies to politicians considered to be dissidents.

Secondly, until political liberalisation took place in 1991, there were no competitive presidential elections in which opposition leaders could participate. Both Kenyatta and Moi were invariably 're-elected unopposed', perhaps in keeping with their respective arrogated titles of 'founding father' and 'father of the nation'. Kibaki ascended to the presidency in 2002 at a time when the political space had been comparatively expanded, so politically savvy competitors were able to cobble together their own ethnic coalitions to stem advantages accrued to him by virtue of his incumbency (Mutua 2008, p 23).

Parliamentary elections in the single-party state were free to the extent that the Kanu inner circle allowed. For this reason Kanu hardly operated as an effective organisation save for its 'gate-keeping' function whereby civic and parliamentary candidates had to be selectively cleared by the party top brass before they contested elections (Berg-Schlosser 1989, p 125). The fact that the electorate was free to pick members of Parliament of their choice should not obscure the fact that the only candidates likely either to be re-elected or to make a maiden appearance in Parliament were those who Moi, the principal patron, and his acolytes supposed would display loyalty and not rock the party from within.

Throughout the era of the one-party state there was a high turnover of politicians, including Cabinet members, in the wake of general elections, but 
that was not a sign of democracy (Berg-Schlosser 1989, pp 126-7). In reality, the electorate simply endorsed those candidates Moi felt would do his bidding. The choreographed selections which passed for competitive elections at parliamentary and civic levels were intended to weed out of the system either politicians whose loyalty to Moi was deemed questionable or those perceived to have political clout.

Thus general elections ensured that, apart from Moi and a few members of his inner circle, the careers of most politicians were in a constant state of flux, resulting in them being preoccupied with their own political survival rather than with putting in place networks to rival Moi's.

At the height of the single-party tyranny Kanu was dormant between elections and would be reactivated at election times only to screen candidates in order to protect the fortunes of the elite rather than to mobilise voters (Khapoya 1980, p 19). The system thrived on corruption, patronage and rent-seeking. ${ }^{4}$

Through patronage, state and public resources are diverted into private hands and the system includes exchanges among the elite as well as the appropriation of public resources by ethno-regional and sectional interests (Haugerud 1995, p 46).

Rent-seeking is inherent in neo-patrimonial regimes. It operates in such a way that a ruler depends on a coterie of 'barons' to manage a political system (Van de Walle 1994, pp133-4). Typically, the ruler recruits these 'barons' from among political allies, personal friends, family, and even erstwhile enemies. In such a system prebends are derived from state agencies which collect government revenues through taxation, regulation and foreign aid, plus agencies whose role in regulating society provides the 'barons' with opportunities for rent seeking and fraud (Van de Walle 1994, pp133-4). Widner (1994, p 53) observes that the most lucrative avenues for rent-seeking in states in which formal institutions are weak include tariffs, credit rationing, foreign exchange rationing, domestic monopolies and monopsonies. Other means by which rent-seeking is executed include all manner of concessions such as tax waivers, loan cancellations and protection from criminal prosecution (Gyimah-Boadi 2007, p 29).

Political contests in Kenya were vicious because incumbents deployed patronage to interfere in the workings of state institutions. For instance, patronage played a crucial role in the manipulation of electoral institutions. The opposition accused Moi of exploiting incumbency to his advantage in the run-up to the 1992 elections after the advent of multiparty democracy. He had the power to announce

4 The exploitation of public office for economic advantage. Rent-seeking entails enrichment through political and bureaucratic positions, allocation of business and trading premises and licences, appropriation of land, contract inflation, kickbacks from multinational corporations, looting of parastatals, fraud and corruption (Ajulu 1995). 
the date of the elections as well as to appoint commissioners to the Electoral Commission of Kenya (ECK). Kibaki seemed to go several notches higher in this patronage-fashioned politics, focusing on winning the 2007 presidential elections by fair or foul means and then invoking state power and incumbency to fight off election challenges, a tactic that is, arguably, emerging as the greatest challenge to the consolidation of democratic tenets in Africa (Gyimah-Boadi 2007, pp 27-8).

Elections, particularly presidential elections, are a life and death affair in Kenya, which is why ethnic sentiment lies beneath the rhetoric of nationalism. It is not difficult to account for this state of affairs: loss of control of the central government in Africa does not simply mean a period in the political wilderness, it spells total economic disaster (Stone 1983, p 90). There is no other explanation for why Kibaki, soon after assuming office, embarked, as had his predecessors, on consolidating power by appointing cronies and political allies to strategic positions in his government and it is in this way that the apparently intractable challenges that have bedevilled Kenya's politics since the early 1990s may be viewed.

Moi vehemently opposed political liberalism, claiming that multipartyism would result in ethnic conflict and chaos and that the one-party state was appropriate for Kenya because it promoted unity among different ethnic groups. In his words political pluralism would result in people 'frying themselves in their own fat' (Apollos 2001). Whereas there is evidence that ethnic conflict, particularly rebellion, hampers democratisation, there is no simple connection between ethnic diversity and political instability or liberalisation/democratisation and ethnic conflict in Africa (Smith 2000).

The official position of Moi's regime was that Kenya's one-party democracy was grounded in traditional African culture, in which decisions are made by consensus as opposed to contest (Haugerud 1995, pp 39, 51). This argument was advanced by most of the first generation of African leaders, foremost among them being Tanzania's Julius Nyerere, who defended the single-party state on the grounds that it had its roots in Africa's past and its traditional form of democracy, which was based on discussion.

A number of scholars have debunked this position (Nabudere 1989, p 1). To analysts like Mutua (2008, p 40) the one-party state was a great disaster for Africa. Mutua posits that rather than being a model form of governance 'it was a demented bandit, looter and terrorist', notwithstanding the exemplary cases of Mauritius and Botswana. Nyong'o (1992, pp 2-3) also repudiates the contention of single-party proponents that Africa will benefit from that form of government.

However, both advocates of multipartyism and analysts of Kenya's politics agree that political liberalisation on its own will not engender political instability unless the ruling party instigates violence (Haugerud 1995, p 39). Thus the rhetoric on the connection between multipartyism and violence was interpreted as being 
aimed at discrediting proponents of multiparty pluralism, particularly the Gikuyu elite, who Moi and some of his more vocal acolytes accused of being driven by self-serving and sectarian interests in their purported quest for political reform (Haugerud 1995, p 39). If the manner in which a cabal of politicians in Kibaki's dispensation frustrated efforts to rewrite the Constitution was anything to go by we would deduce that among certain political elites in Kenya opposition to Moi was driven more by economics and ethnicity than by the need to reform the Kenyan state (Mutua 2008, p 77).

Both Kenyatta and Moi subtly manipulated ethnicity and it was only during the era of multipartyism that the genie of ethnic politics escaped from the bottle and prowled all over the country, leaving, in its wake, property destroyed and thousands maimed or murdered in ethnic clashes. Kenyatta deployed the provincial administration, which falls directly under the Office of the President, to exercise control in farflung areas away from the seat of government in the capital city, Nairobi. Moi used the ruling party, Kanu, to put his finger on the political pulse and repress opposition (Throup \& Hornsby 1998, p 37). Thus the period between 1985 and 1990 was characterised by attempts to construct a state in which politicians settled scores by using the party to harass and intimidate their opponents and, in extreme cases, have their rivals expelled from Kanu, thus freezing their political careers (Throup \& Hornsby 1998, p 37).

\section{MULTIPARTY POLITICS IN KENYA}

It is instructive to note that Kenya experimented briefly with a two-party system for a year after independence in 1963, when Kanu swallowed the Kenya African Democratic Union (Kadu), and between 1966 and 1969, when the Kenya People's Union (KPU) was in opposition (Mutua 2008, p 238; Khapoya 1980, pp 18-19). A 'Little General Election' was held in $1966 .{ }^{5}$ Save for the cited periods Kenya operated as a de facto one-party state until 1982, when it became a de jure oneparty state before reverting to political pluralism in 1991.

The major distinction between the way in which ethnicity manifested itself in one-party states and in multiparty democracies is that in the former the locus of political conflict is at the local constituency level, while in the latter it is at the level of the country as whole (Posner 2007).

True to Moi's prophecy of damnation ethnic clashes engulfed parts of the Rift Valley province, settled by communities considered 'foreign', and led to the loss of lives and property. Ironically, it was the Moi government that politicised the

5 The election was referred to in this way because it was held with the express intention of weeding out of the ruling party dissenting voices which had coalesced under Oginga Odinga's KPU (Ajulu 1995, pp 2-3). 
land issue, despite the fact that it was Moi who had facilitated the resettlement of some Kikuyu in the Rift Valley soon after independence, much to the chagrin of fellow Kalenjin politicians, particularly those from the Nandi and Kipsigis sub-tribes (Throup \& Hornsby 1998, p 29).

The targeted ethnic groups included the Kikuyu, Luo, Luhya and Kisii. Government complicity through the provincial administration was obvious, with administrators, through inaction, tacitly abetting the killing of innocent people. In certain cases they actually aided the marauding gangs which terrorised 'foreign' ethnic groups (Government of Kenya 1992; 1999).

The Moi government's behaviour after acquiescing to multiparty politics was typical of that of a weak state and from 1991 to 1998 politics in Kenya was commercialised, as patronage overtly held sway. During this period the Kenyan state could not perform its functions and the rule of law was beholden to Moi and his courtiers' caprices, resulting in a state of lawlessness in which the veneer of social cohesion flaked off.

A combination of these factors robbed the Moi government of the legitimacy to govern (Apollos 2001). The system skimmed the state for the benefit of a few members of the political elite from selected ethnic communities while the rest languished in economic and political limbo. The rule of law, or what had remained of it, collapsed as the police, in tandem with youth militias, cordoned off certain regions of the country, especially in the Rift Valley, and declared them Kanu zones, from which opposition was barred.

During this period the Kenyan taxpayer was swindled out of astronomical amounts of money by means of a scam dubbed Goldenberg. Through this scheme the Central Bank paid out money to individuals linked to Moi through a fictitious export compensation scheme involving phoney gold. The scandal could be viewed through the prism of patronage politics whereby the ruling elite was in desperate need of money in order to fight off an opposition onslaught. The money was intended to be used to disorganise the opposition and hire more loyalty at a time when Kanu's hold on power was under severe threat.

Though there is an argument that modernity heightens the politicisation of ethnicity there is a counter argument that social networks that link wealthier and better educated individuals across ethnic and local boundaries may lead to the emergence of political ideologies and practices which transcend the politics of prebendalism, clientelism and ethnicity (Haugerud 1995, p 43). The Kenyan case shows that the counter argument is constantly under severe pressure. Though Kenya has a significant middle class ethnic cleavages have perennially torpedoed attempts to reform the nation state. Since the opening of the political space in the early 1990s Kenya has witnessed the unsavoury side of ethnicity. So violent and unsettling has been the interface between ethnicity and pork-barrel politics 
that some analysts have asserted that, save for personality cultism, no power has exerted as much influence on political parties in Kenya since the advent of political pluralism as ethnicity (Mutua 2008, p 21).

The political elites, mostly from the Luo, Luhya and Gikuyu communities, mounted and sustained opposition to Moi's authoritarianism. However, they opposed Moi's highhandedness for different reasons. The Kikuyu elite was driven by nostalgia for the privileges they had enjoyed under Kenyatta, while the Luo and sections of the Luhya felt excluded under Moi, just as they had been under Kenyatta (Mutua 2008). These differences were nonetheless subsumed in a global quest for multiparty democracy. Their clamour for political change was so disparate that when Kibaki succeeded Moi some of Moi's most ardent critics, most of whom had built their political careers on attacking him, embraced the very structures Moi had exploited to abuse power,.

Most political parties in Kenya were in the grip of tribal barons who doubled as the party's financiers and proprietors. Parties have no membership save for supporters who associate with them for purely ethnic reasons, prompting Mutua (2008, p 22) to describe most of them as reservoirs of 'ethnic nativism'. He further observes that demagoguery perennially held sway during electioneering periods as party leaders moved around the country disseminating ethnic-based political myths, distorted histories, and perceived grievances against other groups.

In an attempt to obfuscate the raw nature of ethnic politics in Kenya crossethnic alliances, for example, pairing presidential and vice-presidential candidates of different ethno-regional origins, are constructed (Haugerud 1995, p 43). The 1992 general elections showed the futility of such alliances as manifested in a faction of the Forum for the Restoration of Democracy (Ford) parties. Whereas Ford-Asili's Kenneth Matiba, a Kikuyu, was able to garner substantial votes from the Luhya community by dint of having a running mate, Martin Shikuku, from that community Ford-Kenya's Oginga Odinga's presidential bid fared dismally in Kikuyu dominated areas, including his running mate Paul Muite's own constituency (Mutua 2008, p 87).

In the 1992 general elections, the first such competitive polls since Kenya's return to political pluralism, what was forecast as a landslide opposition victory foundered on the shoals of ethnicity. In the run-up certain sections of the Kikuyu political elite allegedly convinced Matiba, at the time admitted to a London hospital, to run for president because they could not countenance Odinga, a Luo, leading Kenya because he was presumed to be uncircumcised (Badejo 2006, p 165). Matiba's entry into the presidential race led to the bifurcation of the Ford party.

With the splintering of that once formidable opposition party the opposition's chance of dislodging Moi went up in smoke. An assessment of both presidential and parliamentary votes in that year clearly indicates the triumph of ethnic 
ideology over political liberalism (Mutua 2008, p 87). Southall (1998) also located the inability of creating a common political front against Moi in 1992 in what he called 'the minutiae of ethnic politics and the enmeshing web of patronageclient relations and the realization by individual politicians that membership of the political class brings access to the spoils system'. However, Moi's re-election could not be reduced to a simple case of ethnic factionalism within the opposition. Three basic explanations were advanced in the wake of the election results: that Moi and Kanu had rigged them; that Moi and Kanu had won; that the opposition had lost because it had split up. All three contain some truth (Holmquist \& Ford 1994, p 8).

In 1997 Moi easily won his second and last term in office because once again opposition leaders demonstrated that they had learnt nothing from the 1992 defeat and, for the second time, political egos stood in the way of opposition unity. Each of Kenya's five major ethnic groups fielded a presidential candidate, which made it easier for Moi to sail through by scooping votes from almost every ethnic group barring the Luo and Kikuyu communities, from which he was virtually locked out.

The constellation of smaller ethnic groups remained loyal to Moi and, with significant votes from the Luhya community, the second-largest in the country, Moi was home and dry. In the wake of yet another routing by the ruling party it became patently obvious that nothing short of unity would help the opposition wrest power from Moi's clutches.

\section{THE 2002 GENERAL ELECTIONS AND COALITION POLITICS}

In 2002 Kenya held watershed elections that were seen as a mark of transition from arbitrary and personalised leadership to the institutionalisation of governance in constitutional structures. The general elections were also billed as a defining turn in Kenya's political history in the sense that it was expected that they would mark a break from autocracy, impunity, ethnic and rent-seeking politics to a new dispensation characterised by national cohesion, respect for the rule of law, accountability and a general reorientation of Kenya's politics. Hence the phrase 'second liberation', the first having been from colonialism. According to Furley (1995, p 15) the phrase 'second liberation', as applied to African politics, denoted the removal of the old generation of leaders in the early 1990s.

The opposition coalesced under the aegis of the National Rainbow Coalition (NARC) and successfully defeated Moi's anointed successor, Uhuru Kenyatta, the late Jomo Kenyatta's son. NARC was driven by a personal vendetta against Moi for having bypassed them in settling for Kenyatta, a political parvenue. Devoid of any ideological anchor, the grouping lowered the bar: any presidential candidate 
with a realistic chance of defeating Kenyatta was acceptable. Therefore it would be a mistake to regard NARC as reform minded.

It was, however, unequivocal about its mission, which was to win the election and form a better government. Whereas the first part of the mission was accomplished with ease, the formation of a better government proved hopelessly elusive and the coalition grappled with the problem until it collapsed under the weight of constant wrangling, bickering and factionalism. Some of its more candid members stated that the coalition was fired up by a single objective - to remove Kanu from power - and once that was achieved it became mired in infighting (Kadima \& Owuor 2006, p 204).

Against this backdrop the NARC coalition may be analysed within the theoretical framework of coalition politics, known as office-seeking, which assumes that the main goal of political parties is to gain access to power. To proponents of this thesis government formation is a zero-sum scenario in which Cabinet portfolios are the pay-off (Kadima 2006). Office-seeking, according to Kadima (2006, p 8), applies in many African countries where securing posts in government, Parliament, parastatals or the diplomatic corps is extremely competitive in the context of general impoverishment and coalition-building serves as an avenue of access to such positions. However, unlike the situation in Western Europe, where coalitions are formed after elections in the context of the proportional representation electoral system, in Kenya, alliances were formed before the 2002 elections (Kadima 2006, p 8).

Contrary to popular belief Kibaki was not popularly elected in 2002; his ascendancy to the presidency was less the result of a convergence of ideological positions and synthesis of programmes of action among NARC's affiliate parties than of a rickety union of ethnic factions. Kibaki's fellow opposition leaders, with support circumscribed within their ethnic constituencies, opted to place their own presidential ambitions in abeyance and backed him in the hope that he would reciprocate with plum posts in an envisaged collegial government (Daily Nation 23 September 2007).

According to Kadima (2006, p 10) a party coalition is defined as the coming together of a minimum of two political parties for a certain period, in pursuit of an agreed set of common goals to be reached by means of a common strategy, joint actions, the pooling of resources and the distribution of possible subsequent pay-offs. In both the 1992 and 1997 elections the combined votes for the opposition totalled more than those for Kanu and Moi (Hornsby 2001, pp 135-204).

To avoid yet another defeat because of fragmentation opposition parties built a coalition in order to consolidate their voting blocs. NARC settled for Kibaki as its presidential candidate purely on ethnic grounds. Kanu, or rather Moi, had chosen Kenyatta, a Kikuyu, so Kibaki, another Kikuyu, was chosen in order to 
split the populous Kikuyu vote, since the other major ethnic groups were solidly in the NARC fold.

It may be true that some of NARC's leading members were opportunists pursuing self-serving interests but the NARC manifesto indicated that the coalition had certain objectives, among them ending corruption, transforming the country politically and economically, providing free education and empowering the people. Others were to change the Constitution within 100 days of taking power and to establish a parliamentary system of government with a ceremonial head of state and an executive prime minister (Kadima \& Owuor 2006, p 204).

Apart from free primary-school education, which NARC introduced soon after it assumed power, the rest of its pledges were abandoned (Kadima \& Owuor 2006, p 204). Rather than the Kibaki government delivering on a new constitution as promised, it became a stumbling block to the realisation of this aim, just as Moi had been (Human Rights Watch - HRW - 2002, p 9). The government watered down a draft constitution which had taken four years to write and had cost astronomical amounts of tax payers' money. The bastardised draft, popularly known as the Wako Draft, named after the country's attorney general, was eventually rejected in a referendum in 2005, which polarised the country along ethnic lines (European Union Election Observer Mission 2008; Mutua 2008).

Kenyans ushered in multipartyism with single-party structures intact and a single-party mentality among most political leaders. Kibaki, for example, who served Kanu almost his entire adult life, rising to the vice-presidency of the country, was a zealous architect and defender of a single-party behemoth (Badejo 2006, pp 91, 92, 161). It is this 'illusion of change' (Hornsby 2001, p 157) that may account for the seemingly intractable and convoluted reform process in Kenya. Apart from amendments to the Constitution in the mid-1990s, which made provision for more political parties (HRW 2002, p 6), the document remained pretty much as it was under one-party rule.

The twin issues of devolution of power and resource distribution were not constitutionally redressed and it was these issues that turned ethnicity into such an incendiary phenomenon. Comprehensive constitutional reforms to redress the disproportionate concentration of powers in the presidency had not featured prominently among the demands of Kenya's opposition parties in the early 1990s. However, after they were unable to unseat Moi in 1992 and 1997, the opposition realised that the matter deserved priority attention, for the Constitution gave the incumbent an edge over his opponents.

In the 2002 elections the seemingly impossible happened. For instance, the Luo, a community whose son, Oginga Odinga, differed ideologically with Kenyatta, resulting in the former's political ostracism, overwhelmingly voted for Kibaki, a Kikuyu, a move that put paid to Moi's succession game plan, which had 
based Kenyatta's chance of victory on the presumed inability of the Luo to vote for a Kikuyu because the two communities were widely perceived to be mutually antagonistic. The Luhya, a community known as politically liberal in the sense that they had never voted as a bloc, almost unanimously cast their votes for Kibaki, who they had rejected during his presidential bids in 1992 and 1997.

Kibaki disregarded an offered pre-election power-sharing agreement and marginalised the Liberal Democratic Party (LDP) allies of the coalition. Consequently, his administration acquired an ethno-regional bias, with power concentrated among a cabal of individuals drawn from the Mount Kenya region, home to the Kikuyu, and their close cousins, the Meru and Embu, hence the sobriquet 'the Mount Kenya Mafia' (Nasong'o \& Murunga 2007, p 9). Kenyatta had the Kiambu Mafia, Moi the Kabarnet Syndicate (Ajulu 2002, p 262). Bratton \& van de Walle $(1997, \mathrm{p} 8$ ) had Kenya in mind when they pointed out that even after political transitions in Africa the new rulers were often drawn from the same social and political classes as their predecessors, including an ageing generation of old-guard politicians who had served previous regimes.

Kibaki was accused of perpetuating ethnicity as the focal point of governance in Kenya by appointing a disproportionate number of members of the Kikuyu and Meru communities to prominent positions in the Cabinet, state corporations, and the civil service. He squandered an opportunity to dispel the belief held by most ethnic groups that the Kikuyu elite was incurably mendacious and had no regard for the country's ethnic diversity. There were those who believed that the influence of ethnicity in Kenya's politics was neutralised once Kibaki's candidature received overwhelming support from the Luo, a community considered to be the Kikuyu nemesis. This misconception was, perhaps, borne out of the hysteria of the 2002 elections.

Firstly, Kibaki had ascended to power courtesy of ethnic manoeuvring. In Kenyan parlance it was called ethnic calculus or arithmetic and to expect him to rise above a phenomenon of which his presidency was a creature was stretching credulity too far.

Secondly, his political career did not mark him as a reformer. In fact, NARC was similar to Kanu in everything but name. Its top decision-making organ, christened 'The Summit' (Badejo 2006, p 351), was composed mostly of individuals who staged a court rebellion against Moi over the latter's succession plan and who were dyed-in-the-wool single-party apologists without any iota of reform credentials. NARC was a bandwagon, some of whose occupants, recasting themselves as reformers, were implicated in gross economic crimes and human rights abuses, including the politically motivated ethnic clashes that rocked the country in the early 1990s (HRW 2002).

Thirdly, Kenyans from other ethnic groups did not vote for Kibaki because 
his policies resonated with their aspirations. After all, he had run for president twice without success. The question was: what, in 2002, made him appeal to those communities that had previously not considered him capable of leading the country? If one were to aggregate the reasons why Kenyans voted for Kibaki at the time, one might surmise that they were partly the result of Kenyans' frustrations with what they considered to be Moi's misrule and their opposition to what they saw as his intention to institutionalise the Kenyatta dynasty. They were also desperate for unity among opposition parties, hoping that would herald change. But neither they nor the opposition had the time or the capacity to identify the ideal person or group of persons to deliver that change.

Thus one could argue that the quest of Kenyans for institutional and constitutional reforms led them to vote overwhelmingly for Kibaki. The HRW report released in the wake of the post-2007 election violence argued that there was a need to overhaul the entire system of governance in order to address deeprooted problems that had either been ignored or exacerbated by Kenya's successive governments. The report cited ownership and allocation of land, the Constitution, impunity for corruption, and the organisation of political violence as the most pressing issues at the core of Kenya's post-colonial crisis (HRW 2008, p 12).

The NARC coalition collapsed when differences between the constituent political parties, that is, the LDP and the National Alliance Party of Kenya (NAK), proved irreconcilable. In sync with history the fallout assumed a Luo-Kikuyu dichotomy. In the wake of the 2005 referendum defeat Luo Cabinet members and colleagues who mobilised Kenyans against the draft constitution were axed from the government. To shore up support for his government Kibaki co-opted Kanu loyalists in spite of some of them having been involved in the excesses of Moi's regime, including ethnic clashes (Government of Kenya 1992).

The reason why any reform of Kenya's polity had proved such a Sisyphean undertaking is that one of the flaws attendant on the country's re-entry into multiparty politics was that the struggle for reform was largely conducted through forums such as the media, public rallies and, more tragically, through violent ethnic clashes (Ndegwa 1997).

\section{THE POST-2007 ELECTORAL AND POLITICAL CRISIS}

Kenya's near implosion after the bungled 2007 presidential election was a phenomenon many analysts had predicted, given the consistently perilous political trajectory of the country since Kenyatta's rule (Khadiagala 1995; Southall 1998). The image Kenya had acquired prior to December 2007 of 'an island of peace in a sea of turmoil' was a mirage, bearing in mind the country's history (HRW 2002, p 3). Rather its post- election violence confirmed a pattern in Africa's 
politics established in countries like Togo, Côte d'Ivoire, Burundi, Sierra Leone, and Congo Brazzaville (Gyimah-Boadi 2007, pp 27-28).

The three major political parties competing in the 2007 election were incumbent Mwai Kibaki's Party of National Unity (PNU), Raila ${ }^{6}$ Odinga's Orange Democratic Movement (ODM) and Kalonzo Musyoka's Orange Democratic Movement-Kenya (ODM-K). The rest were fringe parties. Uhuru Kenyatta opted to support Kibaki, since, as a Kikuyu, he knew fellow Kikuyu would not choose him above the incumbent, who was a fellow tribesman. It would have been risky for the Kikuyu to try to replace one of their own in a highly competitive presidential election. Kenyatta chose to bide his time and wait for 2012, well aware that with Kibaki ineligible to stand for a further term he was likely to inherit the Kikuyu voting bloc intact.

There was an assumption among ethnic supremacists, particularly within the PNU, that a Luo would never be elected president. In fact, Musyoka latched onto this stereotype in his insistence that he was the best bet for a combined opposition. He jumped ship and appropriated the ODM-K and, for a while, appeared to have pulled the rug from under the feet of Raila and his allies. His moment of political genius was ephemeral, however, because his erstwhile colleagues took back the initiative when they were handed back the ODM, a party that had been hurriedly registered by some obscure individuals after it was successfully used to defeat the government in the 2005 referendum. The intention was to deny the opposition the word 'orange', which had become such a brand in Kenya's politics. Kalonzo bolted when he realised that Raila would rather have the myth of 'Luo unelectability' tested at the ballot than smother his presidential ambitions on the strength of an argument mired in naked ethnic chauvinism.

There are those who bizarrely argued that Raila's natural political home was in the opposition because of his track record as a seasoned oppositionist. People who hewed to this position asserted that if he became president there would be no one to check the government of the day. If the 2007 election shattered any myth it was that no Luo could be elected president. The fact that Raila lost the presidency because of a flawed counting process, courtesy of a compromised electoral commission, was, in a way, a huge psychological boost for Kenya's collective psyche in the sense that it was no longer tenable for anyone to assert that a Luo could not occupy the highest office in the land. However, what is of equal concern is that the fact that Raila 'came within a whisker of winning the presidency"

6 Raila Odinga is often referred to by his first name in order to differentiate him from the senior Odinga, since he is considered to have carved a niche for himself in Kenya's politics that is distinctly different from his father's, though, like his father, he is a seasoned oppositionist.

7 Raila and most supporters of the ODM were convinced he had won but that the incumbent had stolen the election through misuse of the state machinery. 
showed that only members of large ethnic groups in Kenya are perhaps electable (Mutua 2008, p 248).

Though Mutua concedes that the presidential election was flawed, particularly at the counting stage, there are those who would not hesitate to contest his evasive phraseology, which seems to be consistent with the systemic and pervasive mendacity that weighed down Kenya's post-colonial state. In certain quarters it is believed that victory was blatantly stolen from Raila and the ODM.

According to the United States's non-partisan democracy building organisation, the International Republican Institute (IRI), Raila finished six points ahead of Kibaki in the exit poll (McClatchy Newspapers 8 July 2008; McClatchy News Service 9 July 2008; The Standard 10 July 2008). Furthermore, the electorate voted out more than 20 of Kibaki's Cabinet ministers, including his vice-president and leaders of political parties that formed his re-election coalition. Coupled with the fact that the ODM had the highest number of parliamentary and civic seats it was difficult to contend that the Kenyan voter was sophisticated enough to isolate a presidential candidate from his party. For instance, Raila's ODM won 99 parliamentary seats to Kibaki's PNU's 43 (Mutua 2008, p 244). However, the bifurcation of the ODM camp between Musyoka and Raila made the contest too close to call. Had the ODM faced the elections as a single entity, as it did the 2005 referendum, the post-election impasse might not have occurred.

As in the previous multiparty elections ethnic factionalism ensured that the opposition could not hold together. After a hurriedly convened swearing-in ceremony Kibaki appointed Musyoka as his vice-president, with the intention of forming a Central-Eastern Bantu alliance against the Luo-Luhya-Kalejin Western Kenya ODM group, hence splitting the country down the middle (Mutua 2008, p 250).

For the umpteenth time the elections brought to the fore the ethnic incubus in Kenya's voting patterns, with the three major presidential candidates drawing support from their ethnic strongholds. Kibaki retained the Mt Kenya constituency of the Kikuyu, and the linguistically and culturally related Embu and Meru, the bloc on which he launched his presidential bid in 1992 and which had solidly rallied behind him ever since.

Raila drew his following from the Luo, Luhya, Kalenjin and other smaller ethnic groups in the Rift Valley, North Eastern and Coastal provinces, which he cobbled together under an umbrella called the Pentagon - the topmost decisionmaking organ of the ODM, which drew representation from almost all the party's ethno-regional components. Raila demonstrated that he was a master of Kenya's politics in the sense that he knew that in the country's ethnically fractious political landscape the way to craft a winning formula was by cobbling together a coalition 
comprising leaders of the major ethnic groups - a strategy NARC employed successfully against Kanu in 2002 (Mutua 2008, p 240). Musyoka's bedrock was the Kamba community. Although he had a running mate from the Luhya community he fared abysmally among the Luhya. Beneath the patina of an issue-informed election lay raw ethnicity, on which the three presidential contestants hinged their campaigns and their hopes of ascending to the presidency.

Perhaps more than anything else the elections proved that Kenya's nation state is extremely fragile. The 2007 debacle was a strong indictment of the postcolonial leadership for having perilously gambled with ethnicity among Kenya's 40-odd disparate ethnic groups. The near implosion of the country was clear confirmation that there is a great deal of nation-building still to do (Mutua 2008, p 250). The Kenyan polity needs to break a culture of impunity, promote the equitable distribution of resources and stem neo-patrimonial politics. The place to start would be constitutional reform, though that must be accompanied by an ideo-political renaissance among the political elite.

On a positive note, the ODM wing of the opposition, through Raila, attempted to pull the campaign out of the morass of bland, vacuous and incoherent pledges that had characterised previous multiparty campaigns, which revolved vaguely around a supposed commitment to the rule of law, human rights and economic reform. The ODM stumped the entire country, appealing directly to and connecting with the masses the much-vaunted economic boom of Kibaki's first term in office did not reach.

Odinga consistently returned to the vexed question of uneven development among communities and regions with his pledge to decentralise the government - a radical departure from previous election campaigns in which raw ethnicity was the overriding factor (Mutua 2008, pp 249-50). In addition, he pledged to revamp infrastructure as the lifeblood of economic development.

However, even what appeared to be issue-oriented politics had ethnic overtones. The ODM coalition, which was almost a replica of the Orange brigade which had mobilised Kenyans in a referendum against a draft constitution in 2005, was intended to isolate the Kikuyu community. Raila said as much, both during the referendum campaign and during the 2007 election campaign, in which he implored the Kikuyu not to isolate themselves from the rest of the Kenyan people (Mutua 2008, p 242).

Democracy, which underscores individual liberties, gave a people the inalienable right to vote the way they liked and it would be a travesty either to take retributive measures against an individual or community for voting in a particular way or to urge them to ally themselves with other communities if they do not wish to do so. 


\section{CONCLUSION}

This paper has attempted to trace ethnic politics in Kenya from the colonial period to the advent of political pluralism. The theoretical section provides a lens through which to interpret the apparent ethnic incubus in Kenya's politics. If we juxtapose the single-party state with the multiparty era we realise that whereas ethnicity played an overarching role in Kenya's politics in both phases the difference lies in the extent of the ethnic cleavage it induced.

During the time of one-party rule both Kenyatta and Moi deftly manipulated ethnicity for political as well as economic ends. However, state repression against dissent made it difficult for countervailing forces to mobilise around ethnicity in order to challenge the government of the day.

With the opening up of the political landscape after the decriminalisation of multipartyism political mobilisation and voting patterns took on an ethnic dimension, with resultant cyclical ethnic skirmishes in the run-up to or in the wake of general elections. The high watermark of this perilous brand of politics put Kenya's nation state to severe test after the ECK handled the 2007 presidential elections so unprofessionally.

The paper advances the argument that ethnicity per se is not inimical to national solidarity and cohesion, in fact, it could be a boon in cases where certain ethnic groups genuinely feel marginalised and exploit ethnicity to hold the state accountable and demand an equitable distribution of national resources. What is damaging to Kenya's social fabric is the politicisation of ethnicity by wily and demagogic leaders who stump the country whipping up ethnic sentiment by appealing to stereotypes in a bid either to wrest power or to maintain it.

If we depart from the premise that ethnicity is largely a social construct we can confidently opine that it is possible to put in place mechanisms that prevent people's ethnic diversity from threatening their very survival. As a prerequisite for viable politics Kenya must begin with fundamental constitutional reforms, which must include the strengthening of Parliament and other institutions of accountability.

This will not be an easy exercise, bearing in mind that attempts to rewrite the Constitution have perennially fallen prey to sectarian interests, which, as the 2005 referendum showed, often took on an ethnic dimension. In fact, the outcome of that referendum, in which Raila led renegade government ministers in rejecting the draft constitution, was a dress rehearsal for the 2007 general elections. Ethnic voting patterns exhibited during the referendum almost replicated themselves in the 2007 polls.

Kenya urgently needs to revise its electoral system, preferably to include some element of proportional representation and a move away from the simple 
majority, first-past-the-post system (Southall 1998; Mutua 2008, pp 2-3). Such reforms will reduce the stakes during presidential elections. The polity needs a concatenation of reforms as the challenges bedevilling it are legion and there are groupings which have vested interests in the status quo. All in all, it is instructive to analyse the 2007 presidential election against a background of a constitutional structure which gave the sitting president all the aces, making it almost impossible for it to be credible.

\section{REFERENCES}

Ajulu, R. 1992. 'Kenya: The Road to Democracy'. Review of African Political Economy 53.

1993. ‘The 1992 Kenya's General Elections: A Preliminary Assessment'. Review of African Political Economy 56.

1995. 'The Transition to Multi-partyism in Kenya: the December 1992 Presidential, Parliamentary and Municipal Elections'. Working Paper. Grahamstown: Rhodes University.

2002. 'Politicised Ethnicity, Competitive Politics and Conflict in Kenya: A Historical Perspective'. African Studies 61.

Ake, C. 2000. The Feasibility of Democracy in Africa. Dakar: CODESRIA.

Apollos, M. 2001. 'Ethnicity, Violence and Democracy'. Africa Development XXVI (1 \& 2). Available online: www.codesria.org.

Atieno Odhiambo, E. S. 2002. 'Hegemonic Enterprises and Instrumentalists of Survival: Ethnicity and Democracy in Kenya'. African Studie 61(2).

Badejo, B. 2006. Raila: An Enigma in Kenya's Politics. Nairobi: Yintab Books.

Bates, R. 1983. 'Modernization, Ethnic Competition and the Rationality of Politics in Contemporary Africa'. In D Rothchild \& V Olorunsola (eds). State Versus Ethnic Claims: African Policy Dilemmas. Boulder: Westview Press.

Bengal, S. 2008. 'Wrong candidate won in Kenya, exit poll indicates'. McClatchy News Service, 9 July. Available online: http: www.iri.org/newsarchive/ 2008/2008-0709-News-MiamiHerald-Kenya.asp.

Berg-Schlosser, D. 'Democracy and the One-Party State in Kenya'. In D Nabudere \& P Meyns (eds). 1989. Democracy and the One Party-State in Africa. German Association of Political Science.

Berman, B. 1998. 'Ethnicity, Patronage and the African State: The Politics of Uncivil Nationalism'. African Affairs 97(388).

D Eyoh \& W Kymlicka. 2004 Ethnicity and Democracy in Africa. Oxford: James Currey. 
Bienen, H. 1983. 'TheState and Ethnicity: Integrative Formulas in Africa'. In D Rothchild \& V Olorunsola (eds). State Versus Ethnic Claims: Africa Policy Dilemmas. Boulder: Westview Press.

Bratton, M \& N van de Walle. 1997. Democratic Experiments in Africa: Regime Transitions in Comparative Perspective. Cambridge: Cambridge University Press.

Brown, D. 2000. Contemporary Nationalism Civic, Ethnocultural \& Multicultural Politics. London and New York: Routledge.

Chazan, N, P Lewis, R Mortimer, D Rothchild \& S Stedman. 1999. Politics and Society in Contemporary Africa. London: Lynne Rienner Publishers.

Cooper, F. 2002. Africa Since 1940. Cambridge: Cambridge University Press.

Elischer, S. 2008. 'Ethnic Coalitions of Convenience and Commitment: Political Parties and Party Systems in Kenya'. Working paper. German Institute of Global and Area Studies 68. Available online: www.giga-hamburgde/ workingpapers

European Union Election Observer Mission. 2008. 'General Elections 27 December 2007'. ec.europa.eu/external_relations/human_rights/eu_election_ass. observer/kenya07/final_report.en.pdf

Friedman-Sabar, G. 1997. 'Church and State in Kenya, 1986-1992: The Churches' Involvement in the "Game of Change"'. African Affairs 96(382).

Furley, O (ed). 1995. Conflict in Africa. London: I. B. Tauris Publishers.

Government of Kenya. 1992. Report of the Parliamentary Committee to Investigate Ethnic Clashes in Western and other Parts of Kenya. The Kiliku Report. Nairobi: Government Printer.

2008. Commission of Inquiry into the Post-election Violence. The Waki Commission. Nairobi: Government Printer. Available online: www.nation.co.ke/blob/view//483378/data/46260/-/4cocat/-/WakiReport.pdf

Gyimah-Boadi, E. 2007. 'Political Parties, Elections and Patronage: Random Thoughts on Neo-Patrimonialism and African Democratization'. In M Basedau, G Erdmann \& A Mehler (eds). Votes, Money and Violence: Political Parties and Elections in Sub-Saharan Africa. Pietermaritzburg: University of KwaZulu-Natal Press.

Haugerud, A. 1995. The Culture of Politics in Modern Kenya. Cambridge: Cambridge University Press.

Himbara, D. 1994. Kenyan Capitalists: The State and Development. Nairobi: East African Educational Publishers.

Holmquist, F \& M Ford. 1994. 'Kenya: State and Civil Society and the First Year after the Election'. Africa Today 41(4).

Hornsby, C. 2001. 'Election Day and Results'. In M Rutten, A Mazrui \& F Grignon (eds). Out for the Count: The 1997 General Elections and Prospects for Democracy in Kenya. Kampala: Fountain Publishers.

Horowitz, D. 1985. Ethnic Groups in Conflict. Berkeley: University of California Press. Human Rights Watch. 2002. Kenya's Unfinished Democracy: A Human Rights Agenda for 
the New Government 14(10). Available online www.hrw.org/reports.org/2002/ kenya2/

2008. Ballots to Bullets: Organized Political Violence and Kenya's Crisis of Governance 20(1).

Hyden, G. 1983. 'Problems and Prospects of State Coherence'. In D Rothchild \& V Olorunsola (eds). State Versus Ethnic Claims: African Policy Dilemmas. Boulder: Westview Press.

Kadima, D (ed). 2006. The Politics of Party Coalitions in Africa. Johannesburg: EISA/ Konrad Adenauer Stiftung.

Kagwanja, P. 2003. ‘Globalizing Ethnicity, Localizing Citizenship: Globalization, Identity Politics and Violence in Kenya's Tana River Region'. Africa Development XXVIII (1 \& 2). Available online: www.codesria.org

'Politics of Marionettes: Extra-legal violence and the 1997 Elections in Kenya'. In M Rutten, A Mazrui \& F Grognon (eds). 2001. Out of the Count: The 1997 General Election and the Prospects for Democracy in Kenya. Kampala: Fountain Publishers. Kadima, D \& F Owuor. 2006. 'The National Rainbow Coalition'. In D Kadima (ed). The Politics of Party Coalitions in Africa. Johannesburg: EISA/Konrad Adenauer Stiftung.

Kanyinga, K. 1998. 'Contestation over Political Space: The State and Demobilisation of Opposition Politics in Kenya'. In O A Olukoshi (ed). The Politics of Opposition in Contemporary Africa. Uppsala: Nordiska Afrikainstitutet.

2001. 'Mix-and-Match Parties and Persons: The 1997 General Elections in the Meru and Embu Regions of Kenya'. In M Rutten, A Mazrui \& F Grognon (eds). Out of the Count: The 1997 General Election and the Prospects for Democracy in Kenya. Kampala: Fountain Publishers.

Kasfir, N. 1976. The Shrinking Political Arena: Participation and Ethnicity in African Politics with a Case Study of Uganda. Berkely: University of California Press.

Katz, S. 1985. 'The Succession of Power and the Power of Succession: Nyayoism in Kenya'. Journal of African Studies 12(3).

Khadiagala, G. 1995. 'Kenya: Intractable Authoritarianism'. American Political Science Review in School of Advanced International Studies Review: A Journal of International Affairs XV(2).

Khapoya, V. 1988. 'Moi and Beyond: Towards Peaceful Succession in Kenya?' Third World Quarterly 10(1).

Kitching, G. 1980. Class and Economic Change in Kenya: the Making of an African PetiteBourgeoisie. New Haven: Yale University Press.

Le Vine, T. 1997. 'Conceptualising "Ethnicity" and "Ethnic Conflict": A Controversy Revisited'. Studies in Comparative International Development 32(2).

Leys, C. 1975. Underdevelopment in Kenya: The Political Economy in Neocolonialism 19641971. London: Heinemann. 
Lonsdale, J. 2004. 'The Dynamics of Ethnic Development in Africa'. In B Berman, D Eyoh \& W Kymlicka (eds). Ethnicity and Democracy in Africa. Oxford: James Currey.

2008. 'Kenya: ethnicity, tribe, and state'. Open Democracy Online: www. opendemocracy.net

Mamdani, M. 1996. Citizen and Subject: Contemporary Africa and the Legacy of Late Colonialism. Kampala: Fountain Publishers.

McClatchy Newspapers. 2008. 'Kenya's president lost disputed elections, polls show', July. Available online: www.iri.org/newsarchives 2008.asp

Morton, A. 1998. Moi: The Making of an African Statesman. London: Michael O'Mara Books Ltd.

Mutua, M 2007. 'Ethnicity the bane of Kenyan politics'. Daily Nation 23 September. Available online: nationmedia.com/dailynation/printpage. asp?newsid $=107037$ 2008. Kenya's Quest for Democracy: Taming the Leviathan. London: Lynne Rienner Publishing.

Nabudere, D \& P Meyns (eds). 1989. Democracy and the one-party state in Africa. German Association of Political Science.

Nabudere, D. 1989. 'The One-party State in Africa and its Assumed Philosophical Roots'. In D Nabudere \& P Meyns (eds). Democracy and the One-party State in Africa. German Association of Political Science.

Nasong'o S and Murunga G "Prospects for Democracy in Kenya."In Nasong'o S. and Murunga G. (eds) 2007. Kenya The Struggle for Democracy, Dakar, CODESRIA Books.

Nation Daily. 2002. 'The end of an era - as the curtain falls on Daniel arap Moi's 24year rule, a special report on the life and politics of Kenya's second president', 24 December.

Ndegwa, S. 1997. 'Citizenship and Ethnicity: An Examination of Two Transition Moments in Kenya'. The American Political Review 91(3).

Nnoli, O. 1995. Ethnicity and Development in Nigeria. Aldershot: Ashgate Publishing Limited.

Nyong' o, P A (ed). 1992. 30 Years of Independence in Africa: The Lost Decades? Nairobi: Academy Science Publishers.

Olorunsola, V (ed). 1972. The Politics of Cultural Sub-Nationalism in Africa. New York: Anchor Books.

Ogot, B A \& W R Ochieng' (eds). 1995. Decolonization and Independence in Kenya. London: James Currey.

Osaghae, E. 1994. Ethnicity and its Management in Africa: The Democratic Link. Lagos: Malthouse Press Limited.

Posner, D. 2007. 'Regime Change and Ethnic Cleavages in Africa'. Comparative 
Political Studies 40(1302). Available online: cps.sagepub.com/cgi/content/ abstract $/ 40 / 11 / 1302$

Russell, A. 1999. Big Men, Little People: Encounters in Africa. London: Macmillan.

Sandbrook, R. 1985. The Politics of African Economic Stagnation. Cambridge: Cambridge University Press.

Smith, Z K. 2000. 'The Impact of political liberalisation and democratisation on ethnic conflict in Africa: an empirical test of common assumptions'. Journal of Modern African Studies 38(1).

Southall, R. 1998. 'Moi's Flawed Mandate: The Crisis Continues in Kenya'. Review of African Political Economy 25(75).

Standard, The. 2008. 'Raila won last year's election, says US poll', 10 July. Available online: eastandard.net/business / InsidePage.php?id=1143989897\&cid=159\&

Stone, J. 1983. 'Ethnicity Versus the State: The Dual Claims of State Coherence and Ethnic Self-Determination'. In D Rothchild \& V Olorunsola. State Versus Ethnic Claims: African Policy Dilemmas. Boulder: Westview Press.

Sunday Standard 42007.

Swainson, N. 1977 'The Rise of a National Bourgeoisie in Kenya'. Review in African Political Economy 8.

Throup, D \& C Hornsby. 1998. Multiparty Politics in Kenya: The Kenyatta and Moi States and the Triumph of the System in the 1992 Election. Oxford: James Currey.

Van de Walle, N. 1994. 'Neopatrimonialsim and Democracy in Africa with an Illustration from Cameroon'. In J Widner (ed). Economic Change and Political Liberalism in Sub-Saharan Africa. Baltimore: The Johns Hopkins University Press.

Widner, J. 1994. 'Political Reforms in Anglophone and Francophone African Countries'. In J Widner (ed). Economic Change and Political Liberalism in Sub-Saharan Africa. Baltimore: The Johns Hopkins University Press.

Young, C. 1976. The Politics of Cultural Pluralism. London: The University of Wisconsin Press.

1994. 'Ethnic Diversity and Public Policy'. Draft occasional paper for the UN Research Institute for Social Development, World Summit on Social Development, Geneva, August. \& T Turner. 1985. The Rise and Decline of the Zairian State. London: The University of Wisconsin Press.

\section{Interviews}

Professor C J Odhiambo, Johannesburg, 18 October 2008.

Dulo Nyaoro, Johannesburg, 30 October 2008. 